\title{
Primary localized amyloidosis
}

INSERM

\section{Source}

INSERM. (1999). Orphanet: an online rare disease and orphan drug data base. Primary localized amyloidosis. ORPHA:314709

Primary localized amyloidosis is a form of AL amyloidosis (see this term) caused by the aggregation of insoluble amyloid fibrils derived from misfolded monoclonal immunoglobulin light chains usually produced by a plasma cell tumor (see this term) and characterized by localized amyloid deposition with clinical manifestations restricted to the organ involved, most frequently urinary tract (bladder), eye, respiratory tract (larynx, lungs), and skin. 